\title{
MECHANICAL PROPERTY AND MICROSTRUCTURAL CHARACTERIZATION OF VACUUM DIE CAST SUPERALLOY MATERIALS
}

\author{
John J. Schirra, Christopher A. Borg and Robert W. Hatala - Pratt \& Whitney, East Hartford, CT
}

Keywords: Turbine blades, Casting, Die Casting

\begin{abstract}
Application of the vacuum die casting process to high strength, high volume fraction nickel base superalloys and a high usage cobalt base alloy produced material with a novel fine grain, cast equiaxed microstructure. The fine grain structure was retained after HIP (Hot Isostatic Pressing) processing and subsequent heat treatment. Mechanical property testing showed that the fine grain structure resulted in increased strength and reduced stress rupture properties for materials typically produced via conventional investment casting. It should be noted that some of the investment cast alloys showed significant apparent hot tearing when processed through the die casting process due to the high cooling rates observed in the die casting process. The high volume fraction wrought disk/shaft alloy (Gatorized Waspaloy ref. 1) was also processed through the die casting process. A reasonably fine grain structure was achieved, however it was coarser than what is typically observed for the wrought form of the alloy. As would be expected from the coarser grain size, the die cast material exhibited lower strength and improved stress rupture capability relative to the wrought form of the alloy. No attempt was made to optimize the various alloy compositions for improved processing or mechanical property behavior using the die casting process or the die casting process parameters.
\end{abstract}

\section{Introduction}

Die casting; the process where molten metal is injected into the cavity of a metallic die, held for a period sufficient for adequate solidification and then released; has been used widely in various industries, most commonly the automotive and commercial industries. Because of the rapid cooling rates and fine grain sizes combined with the ability to precision machine the die cavity and exploit high injection pressures the die casting process has many advantages over other metal forming processes. These process benefits include improved mechanical properties over conventional casting processes, good surface finish, short cycle times, high volume capacity, good repeatability and dimensional stability. The most commonly used alloys in this process are aluminum, zinc, magnesium and to a lesser extent copper.

Recent efforts have been initiated to apply the die casting process to the production of components for use in the aerospace industry using titanium, nickel and cobalt based alloys. The primary difference in the processing of these non-conventional alloys is that the entire process must be performed under relatively high vacuum to achieve the melt cleanliness required for aerospace applications. (ref.. 2,3,4) The same benefits of conventional die casting can be realized with the vacuum die casting (VDC) process such as thin wall parts (1 to $12 \mathrm{~mm}$ ), tight tolerances, fine microstructure due to the rapid solidification rates and therefore properties approaching that of wrought product, and relatively short cycle times. Figure 1 shows a schematic of the VDC process from reference 2, it is important to note the entire melting, pouring and injection process in conducted under stringent vacuum controls. The part is exposed to atmosphere only after complete solidification has occurred.

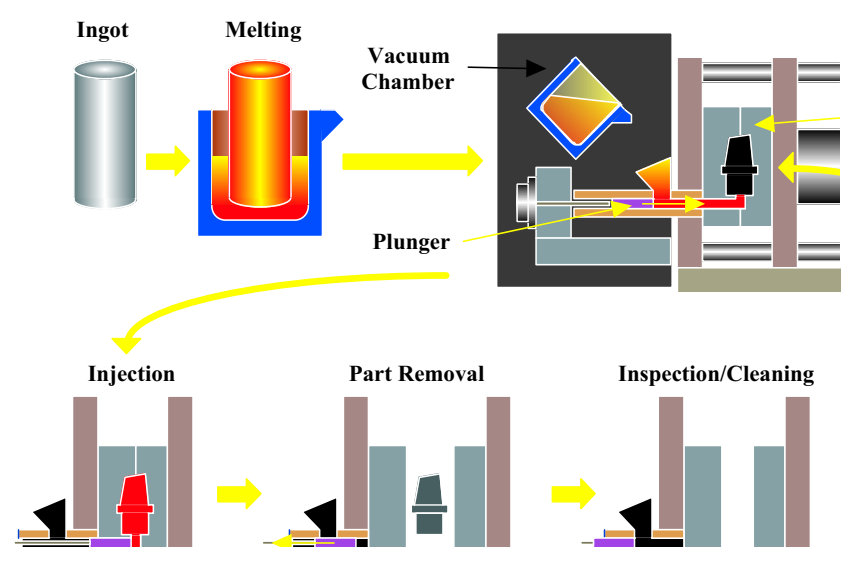

Figure 1. Schematic of Vacuum Die Casting System (Ref. 2).

One of the most common production quality problems encountered in the conventional die casting process is tooling wear and subsequent failure. The presence of the molten alloy flowing at high speeds across the die surface coupled with the stresses induced from the thermal shock of molten metal contacting a cold metallic die. Due to the expense of the precision machined dies and the long lead times for production and repair of the tools, die failure may reduce or eliminate the process benefits mentioned above. This issue is magnified when using reactive, high melting point alloys such as those used for aerospace applications. Die life and die casting process issues associated with aerospace materials will not be discussed as part of this evaluation.

Work summarized in this paper examines the microstructure and mechanical properties of several commonly used superalloys in the aerospace industry. The majority of these alloys are investment cast for use in turbine blade or structural applications, with one high volume fraction $\gamma$ ' wrought disk alloy, Gatorized Waspaloy. Limited post cast processing; specifically HIP and heat treatment evaluations were also investigated. Material behavior characterized includes tensile, stress rupture and high cycle fatigue as well as microstructural and compositional assessments. The results from this evaluation were analyzed and compared against conventionally processed forms of the alloys; both wrought and cast as well as for compressor airfoil applications. This work was conducted as part of a joint development program 
with Howmet Corporation and their technical process assistance is acknowledged.

\section{Details}

As part of an assessment and development of alternate advanced material processing technologies with the potential for lower cost $\mathrm{P} \& \mathrm{~W}$ conducted an evaluation of the vacuum die casting process (references 2 and 5). The activity was focused on evaluation of application of the process to aerospace materials typically used in higher volume, smaller applications such as airfoils. It was also decided to evaluate the performance of materials that are candidates for higher temperature compressor applications such as high volume fraction, wrought alloys or traditionally investment cast equiaxed alloys used for turbine blade applications. A summary of the alloys selected for evaluation and rationale for inclusion are listed in Table I. For the cast alloys standard vacuum induction melted (VIM) stock weighing approximately 14

Table I. Alloys Included in Die Casting Evaluation and Reason for Selection

\begin{tabular}{|l|l|l|}
\hline Alloy & Application & Rationale \\
\hline $\begin{array}{l}\text { Gatorized } \\
\text { Waspaloy }\end{array}$ & $\begin{array}{l}\text { HPC \& LPT } \\
\text { disks }\end{array}$ & $\begin{array}{l}\text { High volume fraction } \gamma \\
\text { wrought alloy }\end{array}$ \\
\hline Inco 939 & $\begin{array}{l}\text { Structural } \\
\text { cases }\end{array}$ & $\begin{array}{l}\text { Highest temperature } \\
\text { structural casting alloy }\end{array}$ \\
\hline Mar M 509 & $\begin{array}{l}\text { Turbine } \\
\text { airfoils }\end{array}$ & $\begin{array}{l}\text { Common equiaxed casting } \\
\text { alloy }\end{array}$ \\
\hline Inco 713 \& 713C & $\begin{array}{l}\text { Turbine } \\
\text { airfoils }\end{array}$ & $\begin{array}{l}\text { Common equiaxed casting } \\
\text { alloy }\end{array}$ \\
\hline B1900\&B1900+Hf & $\begin{array}{l}\text { Turbine } \\
\text { airfoils }\end{array}$ & $\begin{array}{l}\text { Common equiaxed casting } \\
\text { alloy }\end{array}$ \\
\hline Mar M 247 & $\begin{array}{l}\text { Turbine } \\
\text { airfoils }\end{array}$ & $\begin{array}{l}\text { Common equiaxed casting } \\
\text { alloy }\end{array}$ \\
\hline
\end{tabular}

$\mathrm{kg}$ and approximately $73 \mathrm{~mm}$ in diameter were provided for remelting. The wrought alloy stock was provided as pieces sectioned from billet product for subsequent remelt. The alloys were then sectioned into smaller charge sizes $(\sim 4 \mathrm{~kg})$ for VIM remelt using a ceramic crucible and subsequent die casting. Target melt temperatures for each of the alloys are listed in Table II. Melt temperatures were selected to minimize superheat and maximize solidification rate. The alloys were vacuum die cast by Howmet Corporation in their Operhall Research Center in Whitehall, MI as oversize test bars.

Three test bars were produced in each casting run. A typical cast test bar is shown in Figure 2. The bars were approximately $16 \mathrm{~mm}$

Table II. Alloys Selected for Evaluation and Target Melt Temperatures

\begin{tabular}{|l|l|l|}
\hline Alloy & Specification & Target Melt Temperature \\
\hline Mar M 509 & PWA 647 & $1399^{\circ} \mathrm{C}$ \\
\hline Inco 713 C & PWA 655 & $1288^{\circ} \mathrm{C}$ \\
\hline B1900 & PWA 663 & $1302^{\circ} \mathrm{C}$ \\
\hline Mar M 247 & PWA 1447 & $1371^{\circ} \mathrm{C}$ \\
\hline B1900 + Hf & PWA 1455 & $1302^{\circ} \mathrm{C}$ \\
\hline Gatorized Waspaloy & PWA 1113 & $1260^{\circ} \mathrm{C}$ \\
\hline Inconel 939 & PWA 1495 & $1316^{\circ} \mathrm{C}$ \\
\hline
\end{tabular}

in diameter by $305 \mathrm{~mm}$ long. Following casting, the bars were visually inspected, X-ray inspected and characterized using standard metallographic techniques for as cast microstructure. A summary of the qualitative casting quality assessments is presented in Table III. It was believed that HIP processing would be required to ensure adequate quality for turbine engine applications so a heat treat study was conducted to establish HIP temperatures for each of the alloys. Heat treat samples were sectioned from each of the test bars and processed through various simulated HIP thermal cycles. Metallography was then conducted to define a thermal exposure that would homogenize any residual casting segregation while producing little to no grain growth. A summary of the selected HIP parameters is presented in Table IV. After HIP, the test material was processed through the standard solution heat treat and age cycles typically used for the alloys. Details of the heat treat processing are also summarized in Table IV.

Tensile and stress rupture specimens were then machined for most of the alloys with smooth high cycle fatigue (HCF) specimens machined from the die cast Gatorized Wasploy material. Tensile testing was conducted at RT, $454^{\circ} \mathrm{C}$ and $649^{\circ} \mathrm{C}$ and stress rupture testing was conducted at $649^{\circ} \mathrm{C}$ and 689.5 or $758.5 \mathrm{MPa}$ conditions. In addition, the alloys were also tested at their specification stress rupture requirements. Smooth $\mathrm{HCF}$ testing of Gatorized Waspaloy was conducted at $454^{\circ} \mathrm{C}$. Limited metallurgical characterization of the tested specimens was conducted. In addition to the microstructural and mechanical property evaluation, chemical analysis of the die cast material was also completed.

Table III. Visual Assessments of Test Bar Casting Quality.

\begin{tabular}{|l|l|}
\hline Alloy & Observations \\
\hline Inco 939 & Sound casting \\
\hline Mar M 247 & Sound casting \\
\hline B1900 \& B1900+Hf & Excessive pipe \& cracking \\
\hline Inco 713 \& 713C & Solidification cracking \\
\hline Mar M 509 & Some casting porosity \\
\hline Gatorized Waspaloy & Sound casting \\
\hline
\end{tabular}

Table IV. Heat Treat Parameters for Vacuum Die Cast Superalloy Materials

\begin{tabular}{|l|l|l|}
\hline Alloy & HIP Cycle $^{1}$ & Heat Treatment \\
\hline Mar M 509 & $1204^{\circ} \mathrm{C}$ & $1079^{\circ} \mathrm{C} / 4$ hours \\
\hline Mar M 247 & $1204^{\circ} \mathrm{C}$ & $1079^{\circ} \mathrm{C} / 4$ hrs $+871^{\circ} \mathrm{C} / 12 \mathrm{hrs}$ \\
\hline IN713 \& 713C & $1191^{\circ} \mathrm{C}$ & $1079^{\circ} \mathrm{C} / 1$ hour \\
\hline B1900/1900+Hf & $1204^{\circ} \mathrm{C}$ & $1079^{\circ} \mathrm{C} / 4 \mathrm{hrs}+899^{\circ} \mathrm{C} / 10 \mathrm{hrs}$ \\
\hline Inco 939 & $1107^{\circ} \mathrm{C}$ & $1107^{\circ} \mathrm{C}+\mathrm{FHT}$ \\
\hline $\begin{array}{l}\text { Gatorized } \\
\text { Waspaloy }\end{array}$ & $1107^{\circ} \mathrm{C}$ & $\begin{array}{l}1066^{\circ} \mathrm{C} / 2 \mathrm{hrs}+816^{\circ} \mathrm{C} / 4 \\
\mathrm{hrs}+732^{\circ} \mathrm{C} / 8 \mathrm{hrs}\end{array}$ \\
\hline
\end{tabular}

1) All cycles were 4 hours at $103 \mathrm{MPa}$

2) Fully heat treated per specification $\left(1107^{\circ} \mathrm{C} / 2 \mathrm{hrs}+\right.$ cool $3^{\circ} \mathrm{C} / \mathrm{min}$ to $\left.899^{\circ} \mathrm{C}+913^{\circ} \mathrm{C} / 8 \mathrm{hrs}+982^{\circ} \mathrm{C} / 6 \mathrm{hrs}+802^{\circ} \mathrm{C} / 4 \mathrm{hrs}\right)$ 


\section{Results}

Composition. A comparison between the measured compositions and specification requirements for the various castings is presented in Table V. Although the specification requirements are not presented here the castings generally met specification limits with the exception of tramp elements. One trend consistent with previous experience is the apparent pickup of minor amounts of oxygen during the casting process. This appears to be more prevalent for Fe containing alloys. However, the pickup is slight and the results indicate that it highly

Table V. Measured Composition of Vacuum Die Cast Superalloy Materials

\begin{tabular}{|l|l|l|l|l|l|l|l|l|l|l|l|l|l|l|l|}
\hline Alloy & 939 & 939 & $\mathrm{~B} 1900$ & $\mathrm{~B} 1900$ & $\mathrm{~B} 19 \mathrm{Hf}$ & $\mathrm{B} 19 \mathrm{hf}$ & $\mathrm{M} 247$ & $\mathrm{M} 247$ & 713 & 713 & $\mathrm{M} 509$ & $\mathrm{M} 509$ & $\mathrm{M} 509$ & $\mathrm{GW}$ & $\mathrm{GW}$ \\
\hline Sample & $\mathrm{Gate}^{1}$ & $\mathrm{Bar}^{2}$ & $\mathrm{Gate}$ & $\mathrm{Bar}$ & $\mathrm{Gate}$ & $\mathrm{Bar}$ & $\mathrm{Gate}$ & $\mathrm{Bar}$ & $\mathrm{Bar}$ & $\mathrm{Bar}$ & Bar & Bar & Bar & Gate & Bar \\
\hline Casting & $\mathrm{C} 11$ & $\mathrm{C} 13$ & $\mathrm{C} 19$ & $\mathrm{C} 19$ & $\mathrm{C} 20$ & $\mathrm{C} 20$ & $\mathrm{C} 24$ & $\mathrm{C} 25$ & $\mathrm{C} 108$ & $\mathrm{C} 109$ & $\mathrm{C} 5$ & $\mathrm{C} 103$ & $\mathrm{C} 106$ & $\mathrm{C} 24$ & $\mathrm{C} 25$ \\
\hline \hline $\mathrm{Ni}$ & $\mathrm{Bal}^{3}$ & $\mathrm{Bal}^{3}$ & $\mathrm{Bal}^{3}$ & $\mathrm{Bal}^{3}$ & $\mathrm{Bal}^{3}$ & $\mathrm{Bal}^{3}$ & $\mathrm{Bal}^{3}$ & $\mathrm{Bal}^{3}$ & $\mathrm{Bal}^{3}$ & $\mathrm{Bal}^{3}$ & 9.79 & 9.49 & 9.53 & $\mathrm{Bal}^{3}$ & $\mathrm{Bal}^{3}$ \\
\hline $\mathrm{Cr}$ & 22.2 & 22.4 & 8 & 8.06 & 8.2 & 8.2 & 8.4 & 8.3 & 13.4 & 13.4 & 23.2 & 23.5 & 23.5 & 16.1 & 16.1 \\
\hline $\mathrm{Co}$ & 18.5 & 19 & 10.1 & 10.04 & 10.1 & 10.04 & 9.4 & 9.82 & .053 & .056 & $\mathrm{Bal}$ & $\mathrm{bal}$ & $\mathrm{Bal}$ & 13.4 & 13.3 \\
\hline $\mathrm{Al}$ & 1.99 & 1.87 & 5.7 & 5.69 & 5.8 & 5.61 & 5.4 & 5.33 & 5.79 & 5.75 & - & - & - & 2.2 & 2.08 \\
\hline $\mathrm{Ti}$ & 3.68 & 3.7 & 1 & .95 & 1.1 & 1 & .98 & .99 & .85 & .83 & .16 & .2 & .19 & 4.7 & 4.52 \\
\hline $\mathrm{Nb}$ & .95 & 1 & $\mathrm{na}$ & $<.01$ & .006 & $<.001$ & .002 & .0032 & 2.11 & 2.03 & & & & & \\
\hline $\mathrm{Ta}$ & 1.72 & 1.35 & 4.2 & 4.15 & 4.3 & 4.13 & 3 & 2.91 & .005 & .005 & 3.36 & 3.65 & 3.55 & & \\
\hline $\mathrm{Mo}$ & $\mathrm{na}$ & .09 & 6 & 6.06 & 6.1 & 6.08 & .73 & .71 & 4.53 & 4.49 & & & & 4.2 & 4.16 \\
\hline $\mathrm{Hf}$ & $\mathrm{na}$ & $\mathrm{Na}$ & $\mathrm{na}$ & $\mathrm{Na}$ & 1.06 & 1.01 & 1.28 & 1.2 & & & & & & & \\
\hline $\mathrm{W}$ & 1.96 & 1.91 & $<.001$ & $<.001$ & .1 & .1 & 10 & 9.96 & & & 6.84 & 7.06 & 7 & & \\
\hline $\mathrm{C}$ & .14 & .15 & .1 & .1 & .1 & .1 & .15 & .15 & .11 & .11 & .65 & .71 & .78 & .031 & .033 \\
\hline $\mathrm{Zr}$ & .06 & .057 & .057 & .063 & .043 & .041 & .042 & .037 & .053 & .049 & .37 & .45 & .43 & .069 & .058 \\
\hline $\mathrm{Fe}$ & .52 & .24 & .025 & .023 & .029 & .024 & .057 & .058 & .12 & .12 & .18 & .25 & .21 & .094 & .088 \\
\hline $\mathrm{Si}$ & .028 & .025 & .021 & $<.001$ & .03 & $<.001$ & .011 & .007 & .014 & .0094 & .064 & .055 & $<.001$ & .02 & .015 \\
\hline $\mathrm{O}$ & .0059 & .0048 & .0025 & .0028 & .0018 & .0048 & .0025 & .0032 & .0005 & .0012 & .0056 & .0015 & .0053 & .0025 & .0021 \\
\hline $\mathrm{N}$ & .0025 & .0028 & $<.0005$ & .0003 & $<.0005$ & .0003 & .0002 & .0008 & .0011 & .001 & .0016 & .0022 & .0017 & .0009 & .0011 \\
\hline
\end{tabular}

1) Sample from gating area of casting.

2) Sample from cast test bar.

3) Balance of composition.

probable that the vacuum die casting process could meet and satisfy aerospace alloy compositional requirements.

Microstructure. The as cast microstructure was generally uniform and free of gross segregation typically observed in cast

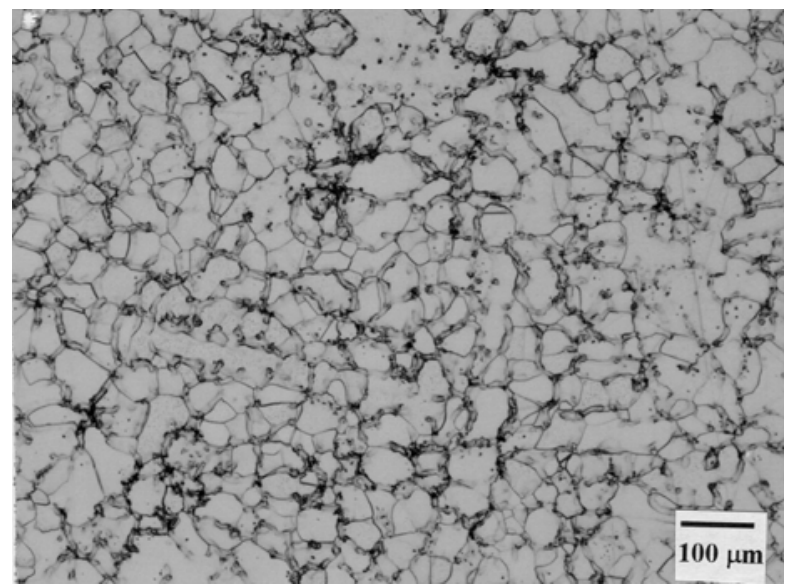

Figure 3. As Cast Microstructure of Vacuum Die Cast Gatorized Waspaloy Exhibiting Fine Grain Size and Little Evidence of Gross Casting Segregation.

superalloys (Figure 3). This is not surprising given the reasonably rapid cooling / solidification rates for the die casting process estimated at $600^{\circ} \mathrm{C}$ or faster. The rapid solidification rates result in an equiaxed structure with grain sizes of ASTM 7 or finer typically observed. For some of the visually sound castings evidence of non metallic inclusions-NMI's (Figure 4) and porosity (Figure 5) were

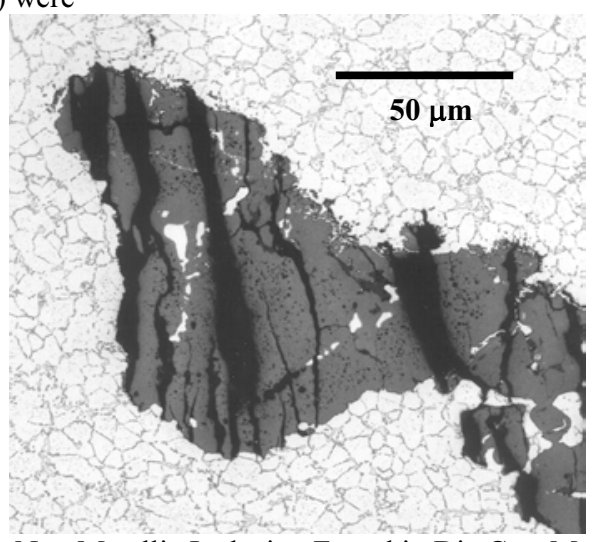

Figure 4. Non Metallic Inclusion Found in Die Cast Mar M 509 Tensile Specimen. Inclusion was Enriched in $\mathrm{Zr}$ Suggesting it Originated from the re-melt Crucible. Cracking is From Tensile Testing.

regularly observed in the material. While the source of the NMI's was not conclusively identified it is possible that it was present in the VIM remelt stock or originated in the crucible used to melt the die casting charge. There are well-established techniques to address these quality issues including the use of skull melting 
processes for the die casting process. Adjustment of casting parameters and gating schemes would also significantly reduce the levels of casting porosity.

Typical microstructures for the fully heat treated materials are presented in Figure 6. It is readily apparent that the desired objectives of maintaining a fine grain size while achieving HIP closure of porosity and homogenization of any residual segregation were achieved. For comparison purposes typical microstructures for the conventional forms of the alloys are also presented in Figure 6 for Gatorized Waspaloy, Inconel 939 and B1900 + Hf. Significant grain refinement is observed for the conventionally cast alloys with a coarser grain structure observed for the conventional wrought alloy (Gatorized Waspaloy).

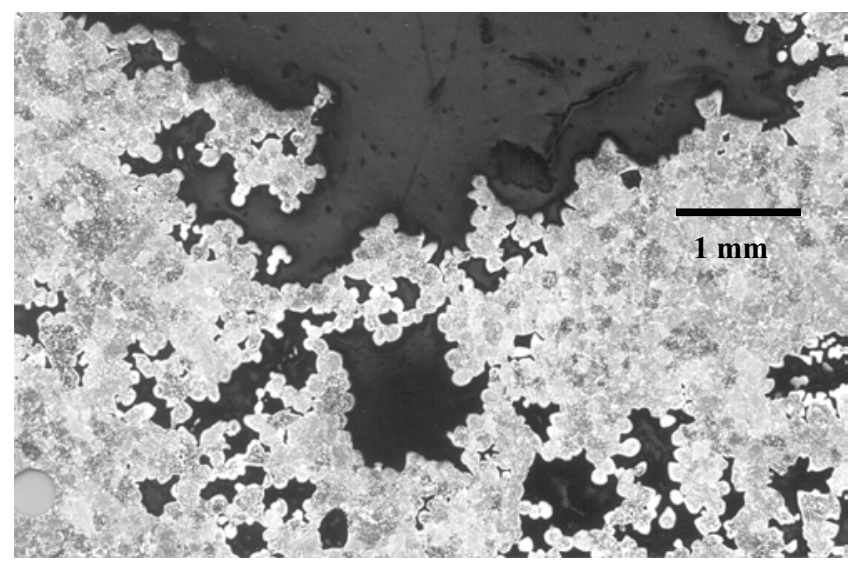

Figure 5. Casting Porosity Found in Die Cast Mar M 247 Tensile Specimen. Porosity is Most Likely Residual Casting Pipe.

Mechanical Properties. Tensile results for each of the materials are presented in table VI. When repeat tests were conducted it is apparent that there is relatively little scatter for the die cast results, consistent with the refined microstructure. There were occasional instances of casting defects resulting in low ductility and UTS in the test material.
Table VI. Tensile Properties of Die Cast Superalloy Materials.

\begin{tabular}{|c|c|c|c|c|c|}
\hline Alloy & Temp & YS(MPa) & UTS(MPa) & EL (\%) & RA (\%) \\
\hline 939 & $22^{\circ} \mathrm{C}$ & 805.3 & 954.3 & 4.7 & 7.2 \\
\hline 939 & $22^{\circ} \mathrm{C}$ & 830.2 & 1236.3 & 9.3 & 10.4 \\
\hline 247 & $22^{\circ} \mathrm{C}$ & 848.1 & 1232.8 & 12.1 & 10 \\
\hline 247 & $22^{\circ} \mathrm{C}$ & 890.8 & 1148.7 & 7.8 & 8.8 \\
\hline 713 & $22^{\circ} \mathrm{C}$ & 810.9 & 1333.5 & 21.2 & 18.4 \\
\hline 713 & $22^{\circ} \mathrm{C}$ & 812.9 & 1283.2 & 17.5 & 17.5 \\
\hline $713 C$ & $22^{\circ} \mathrm{C}$ & 855.7 & 1243.2 & 11.2 & 10.3 \\
\hline 509 & $22^{\circ} \mathrm{C}$ & 547.5 & 994.9 & 7 & 5.2 \\
\hline 509 & $22^{\circ} \mathrm{C}$ & 545.4 & 966.7 & 5.3 & 4.9 \\
\hline GW & $22^{\circ} \mathrm{C}$ & 1088.7 & 1474.8 & 12.2 & 15 \\
\hline GW & $22^{\circ} \mathrm{C}$ & 1088.7 & 1484.5 & 14.8 & 16.1 \\
\hline 939 & $454^{\circ} \mathrm{C}$ & 726.7 & 1140.4 & 12.4 & 13.4 \\
\hline 939 & $454^{\circ} \mathrm{C}$ & 756.4 & 1168.7 & 9.7 & 11.9 \\
\hline 247 & $454^{\circ} \mathrm{C}$ & $\mathrm{Na}^{1}$ & 699.2 & $\mathrm{Na}^{1}$ & $\mathrm{Na}^{1}$ \\
\hline 247 & $454^{\circ} \mathrm{C}$ & 906.0 & 1245.9 & 14.4 & 13.2 \\
\hline 713 & $454^{\circ} \mathrm{C}$ & 817.7 & 1225.9 & 18.2 & 18.4 \\
\hline 713 & $454^{\circ} \mathrm{C}$ & 821.9 & 1190.1 & 17.6 & 15.6 \\
\hline $713 \mathrm{C}$ & $454^{\circ} \mathrm{C}$ & $\mathrm{Na}$ & 1009.4 & 9.6 & 13.2 \\
\hline $713 C$ & $454^{\circ} \mathrm{C}$ & $\mathrm{Na}$ & 1108.0 & 10.8 & 8.6 \\
\hline 509 & $454^{\circ} \mathrm{C}$ & 366.1 & 750.2 & 8.1 & 8.7 \\
\hline 509 & $454^{\circ} \mathrm{C}$ & 359.2 & 777.8 & 8.9 & 9.7 \\
\hline GW & $454^{\circ} \mathrm{C}$ & 1007.4 & 1410.7 & 19.5 & 22.2 \\
\hline GW & $454^{\circ} \mathrm{C}$ & 1009.4 & 1317.6 & 12.2 & 13.9 \\
\hline 939 & $649^{\circ} \mathrm{C}$ & 717.8 & 1224.6 & 16.9 & 15.7 \\
\hline 939 & $649^{\circ} \mathrm{C}$ & 701.9 & 1232.8 & 18.6 & 17.8 \\
\hline 247 & $649^{\circ} \mathrm{C}$ & $\mathrm{Na}^{1}$ & 764.0 & 3 & .8 \\
\hline 247 & $649^{\circ} \mathrm{C}$ & 772.2 & 777.1 & 2 & .88 \\
\hline 713 & $649^{\circ} \mathrm{C}$ & 817.7 & 1190.1 & 21.7 & 25.2 \\
\hline 713 & $649^{\circ} \mathrm{C}$ & 821.2 & 1218.3 & 25.7 & 24.8 \\
\hline $713 C$ & $649^{\circ} \mathrm{C}$ & 816.4 & 870.1 & 3.8 & 5.8 \\
\hline 509 & $649^{\circ} \mathrm{C}$ & 350.3 & 751.6 & 10.7 & 10.8 \\
\hline GW & $649^{\circ} \mathrm{C}$ & 1003.2 & 1380.4 & 12.3 & 13.9 \\
\hline GW & $649^{\circ} \mathrm{C}$ & 974.3 & 1374.9 & 14.2 & 13.1 \\
\hline
\end{tabular}

1) Void in test specimen
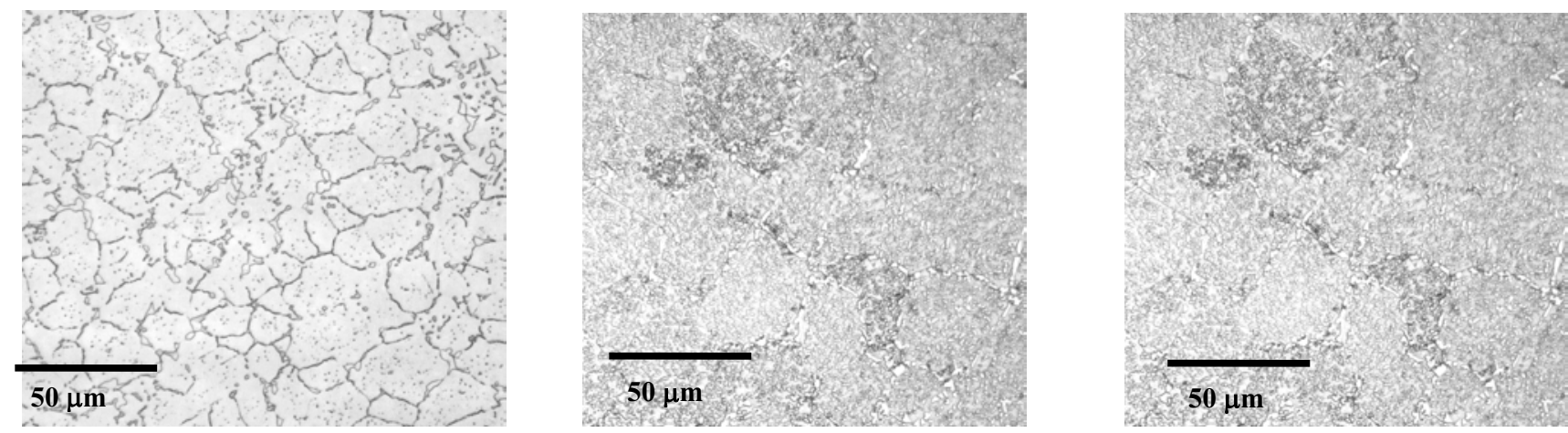

Figure 6. Typical Microstructure of Vacuum Die Cast Mar M 509 (left), Inco 713 (center) and Inco 713C (right). 

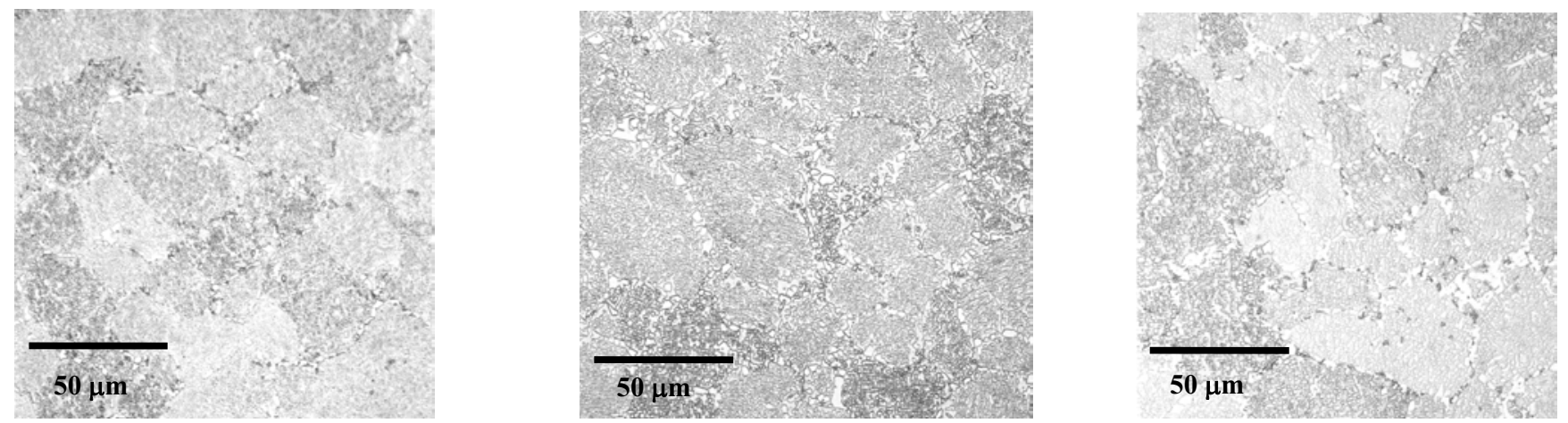

Figure 6. (continued) Typical Microstructures of Vacuum Die Cast B1900 (left), Mar M 247 (center) and B1900 +Hf (right).
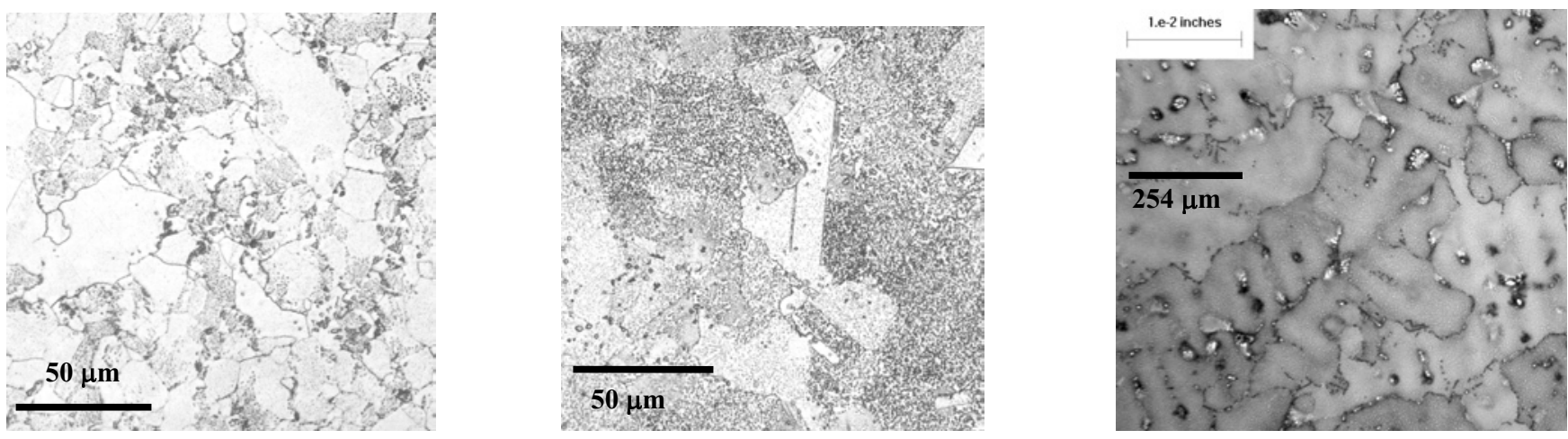

Figure 6. (continued) Typical Microstructures of Vacuum Die Cast Gatorized Waspaloy (left) and Inconel 939 (center) and Investment Cast B1900 +Hf (right).

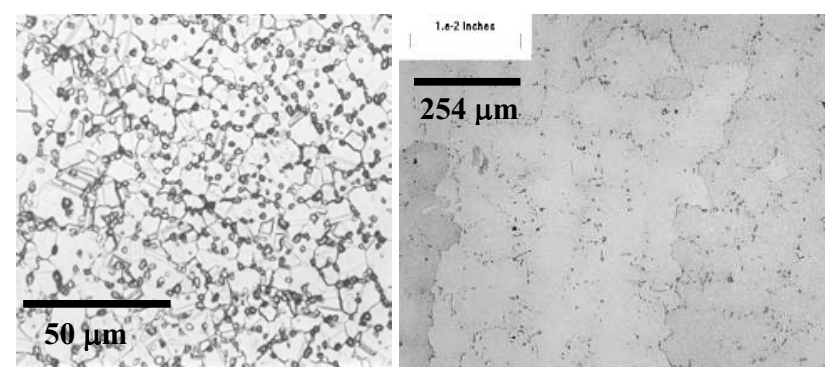

Figure 6. (continued)Typical Microstructure Observed for Conventional Wrought Gator Waspaloy (left) and Conventional Investment Cast Inconel 939 (right).

Stress rupture results are listed in Table VII. Testing was conducted for all alloys at $649^{\circ} \mathrm{C} / 689.5$ or $758.5 \mathrm{MPa}$ conditions and also at specification test requirements for the conventional form of the alloy. Review of the results shows similar behavior to the tensile testing where there is very little scatter in the test results due to the refined and homogenized microstructure.

HCF testing was conducted on Gatorized Waspaloy to assess the characteristics of the alloy for potential die cast high pressure compressor applications. The test results are presented in Table VIII and summarized in Figure 7. Post test fractographic analysis of specimens was conducted and showing some of the failures initiating from casting defects. An example of a typical casting defect initiated fatigue failure is presented in Figure 8. While the
Table VII. Stress Rupture Test Results for Die Cast Superalloys

\begin{tabular}{|l|l|l|l|l|l|}
\hline Alloy & Temp & Stress(MPa) & Life(hrs) & El(\%) & RA(\%) \\
\hline 939 & $649^{\circ} \mathrm{C}$ & 689.5 & 10.2 & 3.7 & 6 \\
\hline 939 & $649^{\circ} \mathrm{C}$ & 689.5 & 158.2 & 3.5 & 2.4 \\
\hline 247 & $649^{\circ} \mathrm{C}$ & 689.5 & $2204.5+$ & - & - \\
\hline 247 & $649^{\circ} \mathrm{C}$ & 689.5 & $2040.1+$ & - & - \\
\hline GW & $649^{\circ} \mathrm{C}$ & 758.5 & 1465.7 & 3.1 & 4.9 \\
\hline GW & $649^{\circ} \mathrm{C}$ & 758.5 & 1499.8 & 5.5 & 7.1 \\
\hline 939 & $816^{\circ} \mathrm{C}$ & 345 & 8.9 & 5.4 & 14 \\
\hline 939 & $816^{\circ} \mathrm{C}$ & 345 & 6.8 & 6.3 & 8.3 \\
\hline 247 & $760^{\circ} \mathrm{C}$ & 689.5 & 49.3 & 2.2 & 3.6 \\
\hline 247 & $760^{\circ} \mathrm{C}$ & 689.5 & 68.1 & 4.1 & 5.4 \\
\hline 509 & $1093^{\circ} \mathrm{C}$ & 62 & 2.7 & - & 24.4 \\
\hline 509 & $1093^{\circ} \mathrm{C}$ & 62 & 2.2 & 51.2 & 73.1 \\
\hline $\mathrm{GW}$ & $732^{\circ} \mathrm{C}$ & 538 & 267.8 & 15.5 & 22.6 \\
\hline $\mathrm{GW}$ & $732^{\circ} \mathrm{C}$ & 538 & 260.4 & 12.6 & 29.7 \\
\hline
\end{tabular}

defects were observed at several of the initiation sites, minimal evidence of porosity related initiation was observed supporting the successful application of HIP processing. In many investment cast superalloys HIP fails to completely heal porosity; a behavior that is attributed to the presence of surface connected shrinkage porosity as a result of the broad solidification range and slow solidification rates observed in conventional investment castings. The rapid solidification rates observed in die casting appear to result in the formation of a continuous casting skin for superalloys (similar to what happens for investment cast titanium) enhancing the response to the HIP cycle. The other predominant initiation site observed in the fatigue testing was crystallographic features 


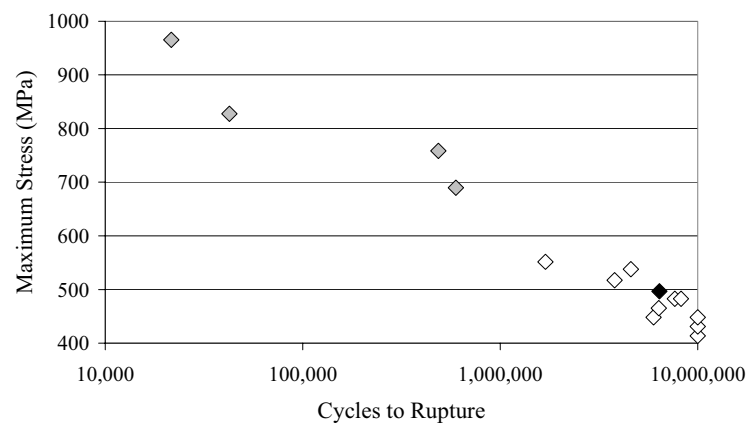

Figure 7. Fatigue Properties of Die Cast Gatorized Waspaloy. Solid Symbols are Defect Related Failures.

across grain facets (Figure 9). Metallographic sections through the faceted areas showed the presence of a localized area of coarser

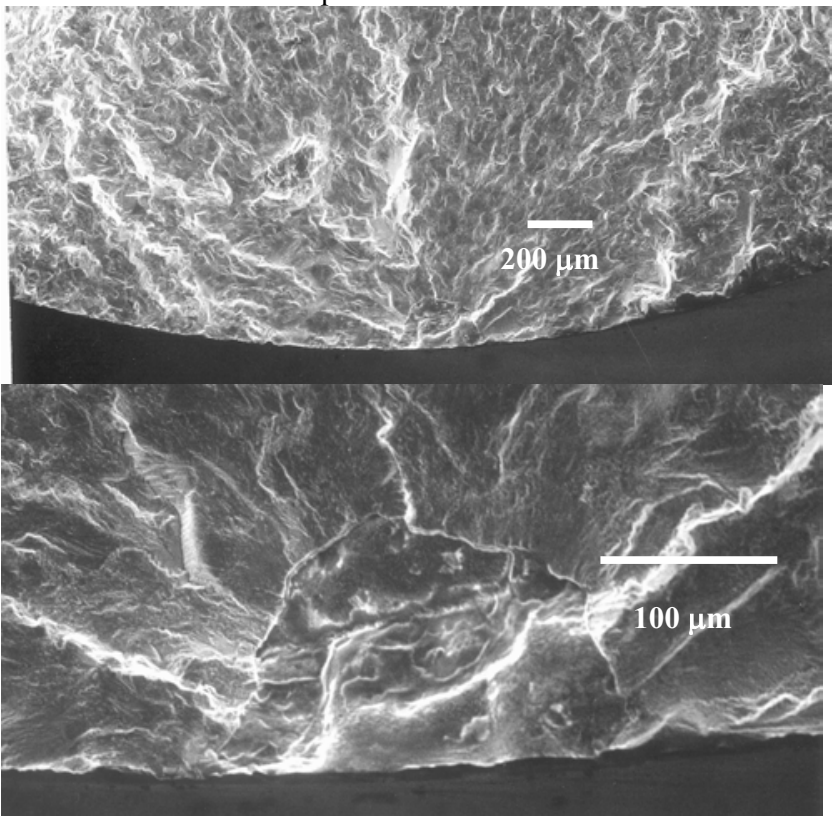

Figure 8. NMI Initiated Fatigue Failure. Origin Area Was Enriched in Aluminum. 21,600 cycles to Failure.

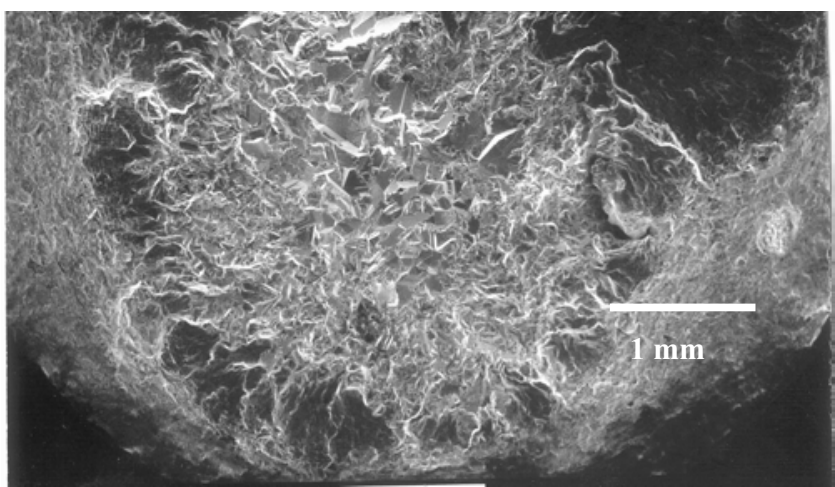

Figure 9. Subsurface Crystallographic Fatigue Origin in Die Cast Gatorized Waspaloy. 1,693,400 cycles to Failure.

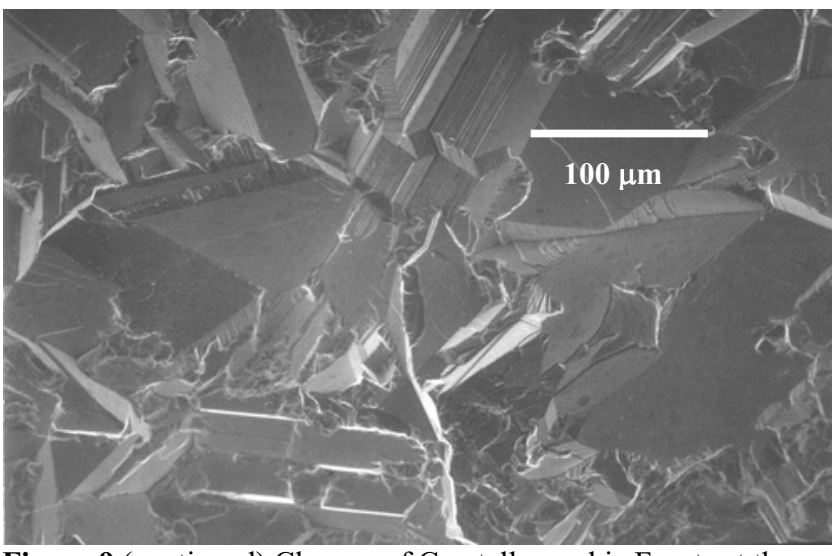

Figure 9 (continued) Closeup of Crystallographic Facets at the Initiation Site.

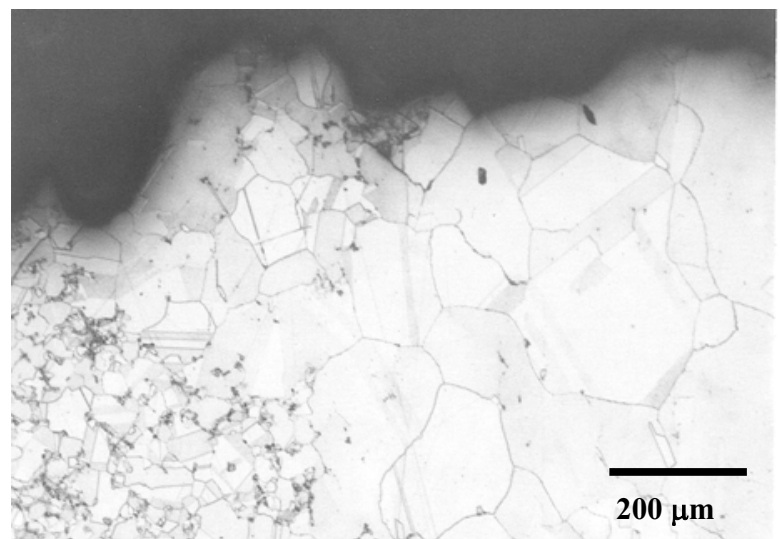

Figure 10. Localized Region of Coarser Grains Associated Crystallographic Initiation Behavior.

\begin{tabular}{|l|l|l|l|l|}
\hline Min $^{1}$ & Max $^{2}$ & $\mathrm{Alt}^{3}$ & Life & Comments \\
\hline 96.5 & 965 & 434 & 21,600 & Oxides at origin \\
\hline 82.7 & 827 & 372 & 42,600 & Oxides at origin \\
\hline 75.8 & 758 & 341 & 486,000 & Subsurface oxides/ facets \\
\hline 69 & 690 & 310 & 595,700 & Subsurface oxides/ facets \\
\hline 55.2 & 552 & 248 & $1,693,400$ & Facets \\
\hline 48.3 & 483 & 217 & $7,651,200$ & Facets \\
\hline 48.3 & 483 & 217 & $8,214,400$ & Porosity with facets \\
\hline 44.8 & 448 & 202 & $5,962,600$ & Facets \\
\hline 41.4 & 414 & 186 & $10,000,000$ & Discontinued \& uploaded \\
\hline 49.6 & 496 & 223 & $6,387,500^{4}$ & Porosity and oxides \\
\hline 43.1 & 431 & 194 & $10,000,000$ & Discontinued \& uploaded \\
\hline 51.7 & 517 & 233 & $3,790,300^{5}$ & Facets \\
\hline 44.8 & 448 & 202 & $10,000,000$ & Discontinued \& uploaded \\
\hline 53.8 & 538 & 242 & $4,586,200^{6}$ & Facets \\
\hline 46.5 & 465 & 209 & $6,343,400$ & Facets \\
\hline
\end{tabular}

1) Minimum stress in $\mathrm{MPa}$

2) Maximum stress in $\mathrm{MPa}$

3) Alternating stress in $\mathrm{MPa}$

4) Uploaded to maximum stress of $496 \mathrm{MPa}$ after $10^{7}$ cycles at $414 \mathrm{MPa}$

5) Uploaded to maximum stress of $517 \mathrm{MPa}$ after 10 cycles at $431 \mathrm{MPa}$

6) Uploaded to maximum stress of $538 \mathrm{MPa}$ after $10^{7}$ cycles at $448 \mathrm{Mpa}$ 
grains associated with the faceted region (Figure 10). The origin of the coarser grain bands could be due to several reasons. The first is that they could be areas of locally solute lean areas due to residual casting segregation. However, the coarse grain bands tend to be located in the center of the cast test bars where one would expect to find solute rich regions if casting segregation was present. The second cause could be related to the presence of areas of casting porosity that are subjected to highly localized deformation during the HIP process. This results in the presence of sufficient strain to produce recrystallization and grain growth during the balance of the thermal processing. The structure could also result from an interaction of the two mechanisms.

\section{Discussion}

Wrought Alloys. One potential application for die cast superalloy materials is to develop a lower cost process for the fabrication of improved capability compressor airfoil materials. To meet this requirement the process/alloy combination must result in material capability comparable to that of forged Inconel 718. Gatorized Waspaloy is a good candidate for this because while representing a wrought alloy, it is at the limit of wrought processing and as such would be very difficult (expensive) to fabricate into forged airfoils. In addition, the strategy used to develop the alloy was targeted at producing a material that had higher temperature capability than Inconel 718. A comparison between the die cast Gatorized Waspaloy results with respect to forged Inconel 718 and conventionally processed cast + wrought Gatorized Waspaloy is presented in Figures 11 and 13. It is apparent that the die cast Gatorized Waspaloy exhibits lower YS and comparable UTS to wrought 718 at the lower test temperatures, and significantly lower fatigue capability relative to wrought Inconel 718. In addition, the stress rupture life of die cast
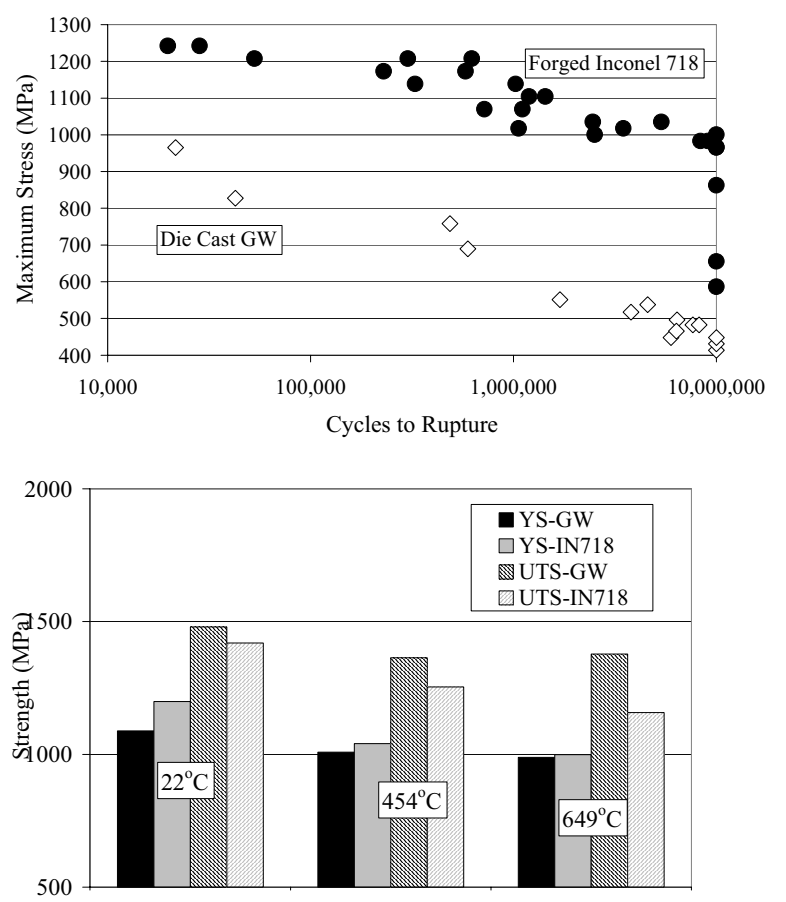

Figure 11. Comparison of the Strength and Fatigue Properties of Die Cast Gatorized Waspaloy Compared with Forged Inconel 718 Typically used for Compressor Airfoil Applications
Gatorized Waspaloy is significantly improved over both wrought Inconel 718 and wrought Gatorized Waspaloy. Again, this is consistent with the coarser microstructure of the die cast material and alloy formulation of Gatorized Waspaloy.

Cast Turbine Alloys. A second potential application for die cast superalloy materials is as a lower cost alternative to investment casting for the fabrication of cast, solid equiaxed low pressure turbine blades. To be successful in this application the material must exhibit properties comparable to the conventional investment cast alloys. In addition, advanced engine designs are driving to increased compressor operating temperatures that will require the application of alloys typically utilized in turbine applications as high compressor blades. When applied to the high compressor, these materials will experience higher vibratory loads than they do in the low turbine. As such the improved strength and fatigue capability achieved with microstructural refinement due to the die casting process, even when balanced against the associated reduction in creep rupture capability, might result in a property balance that is highly desirable for compressor applications. A comparison between the die cast results and typical investment cast results for the various cast equiaxed turbine airfoil materials is presented in Figures 12 and 13. Consistent with the observations for the wrought material, the die cast versions of the alloy show significantly improved strength and reduced rupture capability relative to the investment cast forms of the alloy. Relative to forged Inconel 718, the materials show slightly lower strength at low and intermediate temperatures $\left(<454^{\circ} \mathrm{C}\right)$ where the $\gamma$ " phase results in significant strengthening of Inconel 718 relative to the $\gamma^{\prime}$ strengthened alloys. However, this benefit decreases with increasing temperature and the die cast superalloys would be expected to show improved strength at temperatures $>649^{\circ} \mathrm{C}$, the current limit for most operational commercial transport engines. Review of the stress rupture comparisons shows that, while the die cast superalloys are at or below specification minimums they are significantly better than wrought Inconel 718. This indicates that while die cast, high volume fraction superalloys might have limited application in higher temperature low pressure turbine environments, they might exhibit an optimum balance of properties for increased temperature compressor blade applications.

Fatigue Capability. Critical to any potential airfoil application is the demonstration of adequate fatigue capability. A comparison between the fatigue capability of cast Gator Waspaloy and forged Inconel 718 at $454^{\circ} \mathrm{C}$ (Figure 11) shows that the wrought material exhibits significantly improved capability over the cast alloy. This is partly due to the unique strengthening mechanisms operational in wrought IN718. While the presence of defects might contribute to some reduction in fatigue capability for the die cast product, the test results appear to fit a uniform distribution suggesting that the defects do not significantly influence the fatigue behavior. It is highly probable that improvements in the casting process and associated improvements in the cast material microstructure would increase the sensitivity to casting defects. With respect to the superior forged material fatigue capability it is most likely due to the grain refinement achieved during deformation imparted during the forging operations. For successful application of die cast superalloys as an airfoil material, process economics and business cases must be satisfied and enhancements to the casting process to achieve improved casting quality must also be demonstrated and implemented. 

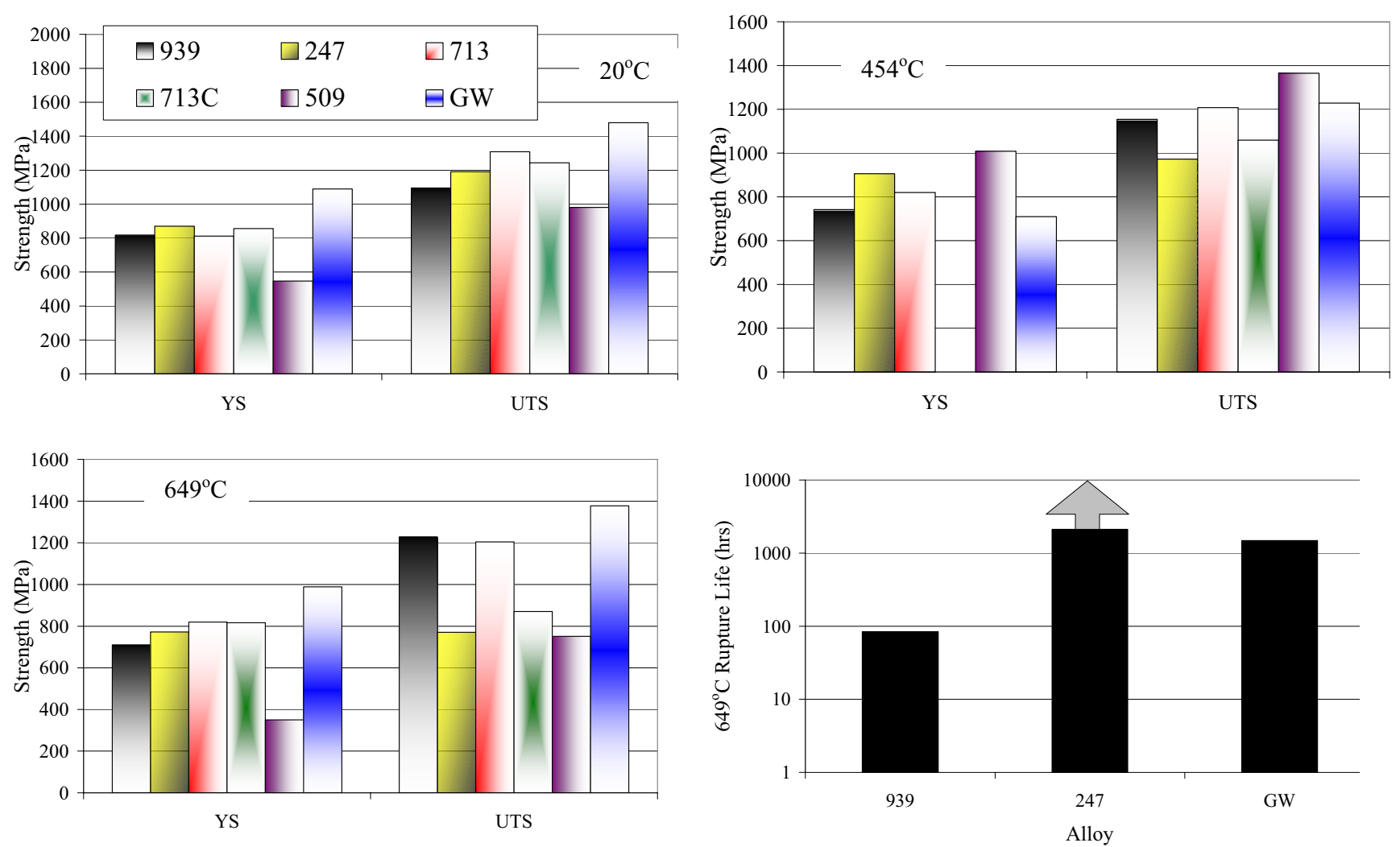

Figure 12. Average Room Temp., $454^{\circ} \mathrm{C}$ and at $649^{\circ} \mathrm{C}$ Tensile Strengths for Die Cast Superalloys and Average Stress Rupture Life at $649^{\circ} \mathrm{C}$.
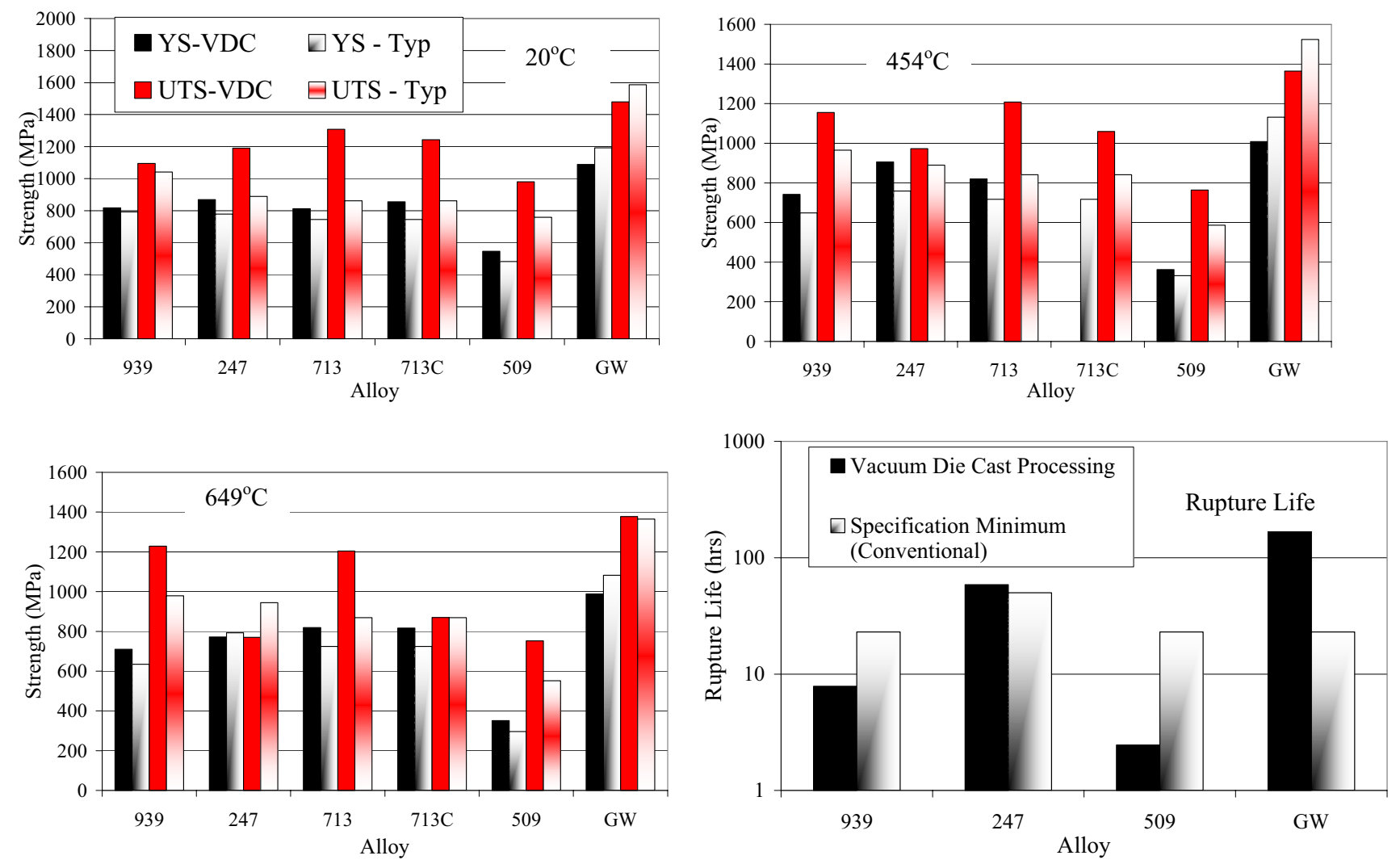

Figure 13. Comparison of the Properties of Die Cast Superalloys (solid) with Typical Strengths and Specification Stress Rupture Requirements for the Conventional Form of the Alloy 


\section{Summary}

The application of vacuum die casting to superalloy materials offers the potential to develop novel refined material microstructures for a broad range of alloy compositions. As would be expected due to the presence of a refined grain size, the mechanical properties of material traditionally produced via investment casting for turbine blade applications show improved tensile and reduced stress rupture capability. Wrought high volume fraction $\gamma^{\prime}$ disk alloys exhibit reduced strength and significantly enhanced stress properties. The highest temperature capability structural casting alloy (Inco 939) shows improved strength and reduced stress rupture life. The combination of mechanical property balance ability to fabricate complex shapes should offer the opportunity to exploit die cast superalloys in niche applications in the temperature range of $649^{\circ} \mathrm{C}$ to $816^{\circ} \mathrm{C}$ if reasonable rupture capability is required. To be successful, the process must offer an economic as well as technical advantage. Improvements to casting quality would be required to meet aerospace requirements and it is highly likely that this could be achieved with investment in the technology.

\section{References}

1. P. D. Genereux, C. A. Borg; "Characterization of Freckles in a High Strength Wrought Nickel Superalloy"; Superalloys 2000; The Minerals Metals and Materials Society; 2000; Ed T. M. Pollock et al; pgs 19-27

2. D. Whitaker, J. J. Schirra, P. R. Bhowal, D. W. Anderson, C. A. Borg; "Vacuum Die Casting of Titanium Compressor Components for Gas Turbine Engines"; AeroMat 2001; $12^{\text {th }}$ AeroMat Conference \& Exposition; June 2001

3. D. Larsen and G. Colvin; "Vacuum-Die Casting Titanium for Aerospace and Commercial Components"; JOM, 51 (6) (1999); pgs 26-27

4. D. Larsen; "Vacuum Die-Casting Yields Quality Parts"; Foundry Management and Technology; February 1998; pgs 43-47

5. J. J. Schirra, C. A. Borg; R. W. Hatala; "Characterization of Vacuum Die Cast Inconel 718 and Derivatives (PWA1472/PWA1473)"; Superalloys 718, 625, 706 and Various Derivatives; The Minerals Metals and Materials Society; 2001; Ed E. A. Loria; pgs 627-636 
